\title{
MAIN AGENTS OF OPPORTUNISTIC INFECTIONS OF GENITOURINARY TRACTS AND THEIR ANTIBIOTIC RESISTANCE
}

Gleb Bondarenko

Department of sexually transmitted diseases $S E$ «Institute of Dermatology and Venerology of National Academy of Medical Sciences of Ukraine» 7/9 Chernyshevka str., Kharkiv, Ukraine, 61057 idvnamnu@ukr.net

\section{Svetlana Dzhoraeva}

Laboratory of Microbiological

SE «Institute of Dermatology and Venerology of National Academy of Medical Sciences of Ukraine» 7/9 Chernyshevka str., Kharkiv, Ukraine, 61057

\section{Anna Kondakova}

SE «Institute of Dermatology and Venerology of National Academy of Medical Sciences of Ukraine» 7/9 Chernyshevka str., Kharkiv, Ukraine, 61057

\section{Iuliia Shcherbakova}

Department of study of the effect of the HIV epidemiconthe problem of sexually transmitted infections SE «Institute of Dermatology and Venerology of National Academy of Medical Sciences of Ukraine» 7/9 Chernyshevka str., Kharkiv, Ukraine, 61057

\section{Nataliya Sobol \\ Laboratory of Clinical}

SE «Institute of Dermatology and Venerology of National Academy of Medical Sciences of Ukraine» 7/9 Chernyshevka str., Kharkiv, Ukraine, 61057

\section{Helen Ivantsova \\ Laboratory of Clinical} SE «Institute of Dermatology and Venerology of National Academy of Medical Sciences of Ukraine» 7/9 Chernyshevka str., Kharkiv, Ukraine, 61057

\section{Abstract}

Today the one of most important medical-social problems is a growing antibiotic resistance of opportunistic infectious agents.

Aim of research: the dynamic observance of antibiotic resistance of opportunistic pathogens - infectious agents of genitourinary tracts under conditions of venereological clinic.

The study included 2205 patients with inflammatory diseases of genitourinary tract, who were on the stationary treatment at the department of venereology of SI "IDV NAMS of Ukraine". Bacteriological studies for isolation of conventionally pathogenic microorganisms with determination of sensitivity of separated laboratory strains to antibacterial drugs of the different groups were carried out using the methods of classic bacteriology.

It was demonstrated, that the composition of microbiocenosis of genitourinary tract in patients with infections, caused by conventionally pathogenic microorganisms was characterized by the prevalence of aerobic representatives of Enterobacteriaceae and Staphylococcaceae families that formed associations both between each other and with representatives of other taxonomic groups. 
The analysis of antibiotic sensitivity of separated strains testifies to the necessity of permanent microbiological monitoring of opportunistic infectious agents for elaborations of the regimes of rational antibacterial therapy.

Keywords: microbiocenosis of genitourinary tracts, conventionally pathogenic microflora, sensitivity to antibacterial drugs.

\section{Introduction}

Inflammatory diseases of genitourinary tracts remain the urgent medical problem because of high morbidity, chronic course, insufficiently effective therapy with possible development of relapses or residual manifestations of an infection [1,2]. The cause of infectious process in genitourinary tracts may be both obligate pathogens and conventionally pathogenic (aerobic, facultative and obligate-aerobic) microorganisms. The biota of genitourinary tract is characterized by individual population of microflora, conditioned by the diversity of interrelations of vegetating microorganisms, their antagonism and synergism. The normal content of genitourinary biotope is constant but at unfavorable states there takes place the shift of microbiota components with abrupt decrease of resident microflora concentration, the tendency to increase of the number of facultative-anaerobic and aerobic microorganisms is traced $[3,4]$. The disorder of ecological balance of this biotope results in the decrease of colonization resistance of mucosae that, in its turn, favors the formation of new microbial associations, usually of representatives of Enterobacteriaceae and Staphylococcaceae families that can mutually strengthen their pathogenic properties. The leading link in the therapy of infectious diseases, partially caused by opportunistic pathogens, is the prescription of antibacterial drugs. But in the case of revelation of microorganisms association in bacteriological inoculation, there is a question of antibiotics choice, because inflammatory agents can belong to different taxonomic groups and have differences in their sensitivity to antibacterial drugs. The other side of this question is microorganisms' resistance that recently reached the menacing scopes.

More than $70 \%$ of infections are caused by microorganisms, resistant to one or more antibiotics [5]. Antibiotic resistance appeared practically immediately, when the active use of antibacterial drugs started and perceptible clinical effects appeared. The further inclusion of antibiotics in all schemes and protocols of the treatment of bacterial infections, widening of scopes and arsenal of practical use of antibiotics resulted in growth of the number of stable strains of microorganisms $[6,7]$. In the global report of World Health Organization, WHO "Resistance to antimicrobial drugs", published in April of 2014 the main threat of effective prophylaxis and treatment of bacterial diseases, namely, resistance to antibiotics was determined. The inclusion of state sectors and society in whole in solving of this problem must be the crucial action for health protection of population throughout the world. The node directions of the fight with antibiotic resistance are: monitoring of microbial agents resistance and strict control over antibiotics use, studies in antibiotic therapy, regular support and exchange of information about appearing resistance, propagation of the rational use of antibiotics [8].

The resistance to antibacterial drugs is typical for most microbes. It is well-known, that more than $70 \%$ of nosocomial strains of enterobacteria produce $\beta$-lactamases of extended spectrum of action that makes them insensitive to all unprotected $\beta$-lactame antibiotics, especially, cephalosporins and carbapenems $[9,10]$. Near $20 \%$ of P.aeruginosa strains are resistant to practically all available antibiotics, except polymyxin. Progressive frequency of separation of staphylococci with different types of antibiotic resistance causes concern last years. The number of strains with resistance to macrolides, that often spreads on lincosamides and streptogramin B, so called MLS-resistance, increases [10, 11]. The studies, realized by Frakking F. N. et. al. (2013) demonstrated that at an infection of genitourinary tracts E. coli occupies 1 place, K. pneumoniae - 4-th, Enterobacter sp. - 6-th, P. mirabilis - 7-th place by frequency among most spread pathogens [12]. $K$. pneumoniae and E. coli - as the producers of ESBL - often demonstrate resistance to many drugs. Today these strains form in out-hospital conditions. 
The serious concern of medical community is caused by the spread of enterobacteria, producing carbapenemases with border sensitivity to carbopenems that essentially decreases the effectiveness of treatment of infections, caused by them [13].

According to the studies, realized by L. Johnson et al (2008), there is observed the increase of Escherichia coli resistance to levofloxacin [14]. At the same time the tendency to the growth of the number of aerobic microorganisms' strains to ampicillin and co-trimoxazole is observed in many countries $[9,15]$. There is observed the growth of staphylococci strains with the resistance to macrolides that often spreads on lincosamides, related to them [16]. This all conditions the necessity of permanent microbiological monitoring of the resistance of representatives of conventionally pathogenic flora as possible etiological agents of infectious diseases to antibacterial drugs of different groups.

\section{Aim of research}

The dynamic observance of antibiotic resistance of opportunistic pathogens - infectious agents of genitourinary tracts under conditions of venereological clinic.

\section{Materials and methods}

In the period of 2013-2016 years there were examined 2205 persons (1158 women and 1047 men) with inflammatory diseases of genitourinary tract, who were on the stationary treatment at the venereological department of SI "IDV NAMS of Ukraine". The complex of laboratory studies included bacterioscopic and bacteriological study of the clinical material, received from the low sections of genitourinary tract. The bacteriological studies for isolation of conventionally pathogenic microorganisms with determination of sensitivity of separated laboratory strains to antibacterial drugs of different groups were carried out according to international protocols and normative documents of MH of Ukraine [17-21].

The general number of patients with separated microorganisms that turned out to be trigger factors of inflammation was 1485 (67,3\%) persons, among them 848 women $(73,2 \%)$ and 637 men $(60,8 \%)$.

Resistant and moderately resistant microorganisms were combined in the group of insensitive strains. The control of quality of determination of microorganisms' sensitivity to antibiotics, quality of used reagents (nutritive mediums and disks with antibiotics) was carried out using the control strains of American typical cultures collection (ATCC): E. coli ATCC 25922, S. aureus ATCC 25923, P. aeruginosa ATCC 27853, E. faecalis ATCC 29212.

\section{Results of research}

The special attention is paid to microbiological monitoring throughout the world; it is carried out for microorganisms that have etiological importance. This method favors the control of actual agents of inflammatory diseases of microbial genesis. As far as the frequency of genitourinary diseases of bacterial etiology remains rather widespread and doesn't have a tendency to decrease, we realized the analysis of prevalence and sensitivity to antibacterial drugs of the different groups of laboratory strains of opportunistic agents that turned out to be etiological factors of patients' diseases. The general number of separated strains of microorganisms was 1602, that related to 10 genera. On the Fig. 1 is presented the structure of microflora, separated in patients with inflammatory diseases of genitourinary tract.

The specific identification of staphylococci and enterobacteria as most etiologically significant microbial agents was carried out (Fig. 2, 3).

The determination of sensitivity of separated laboratory strains of microorganisms to antibacterial drugs of different groups was carried out at the next stage. The received data are presented on the Fig. 4, 5.

On the Fig. $\mathbf{5}$ are presented the data on determination of resistance of separated laboratory strains of enterobacteria to antibacterial drugs. 


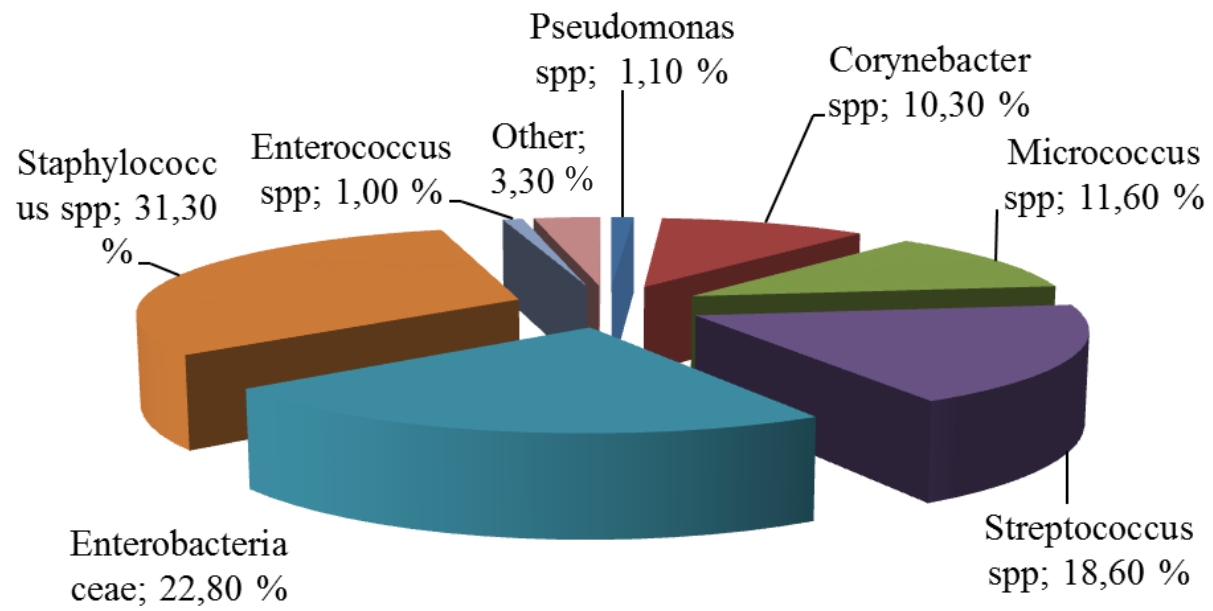

Fig. 1. Structure of microflora, separated in patients with inflammatory diseases of genitourinary tract

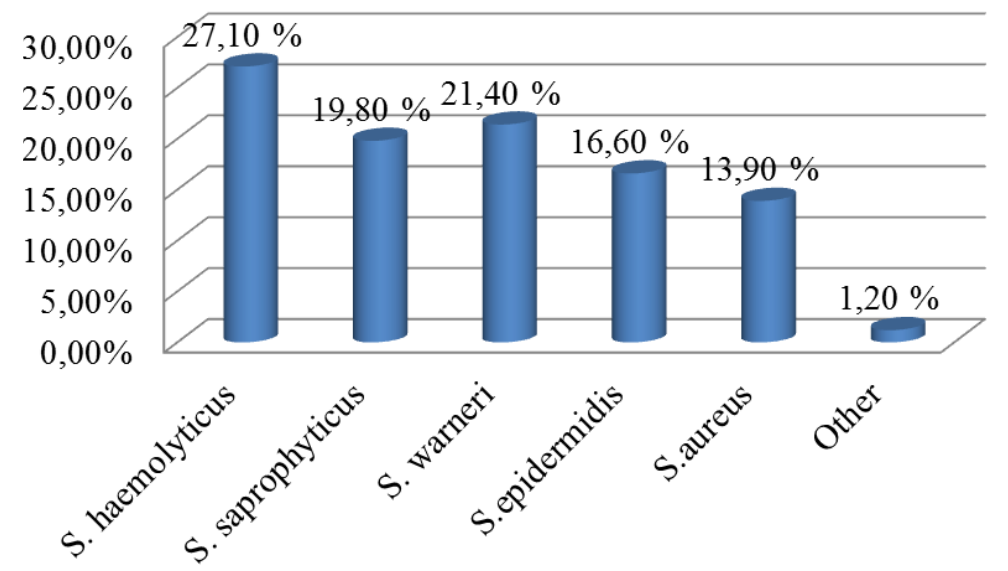

Fig. 2. Species composition of Staphylococcus microorganisms, separated in patients with genitourinary diseases

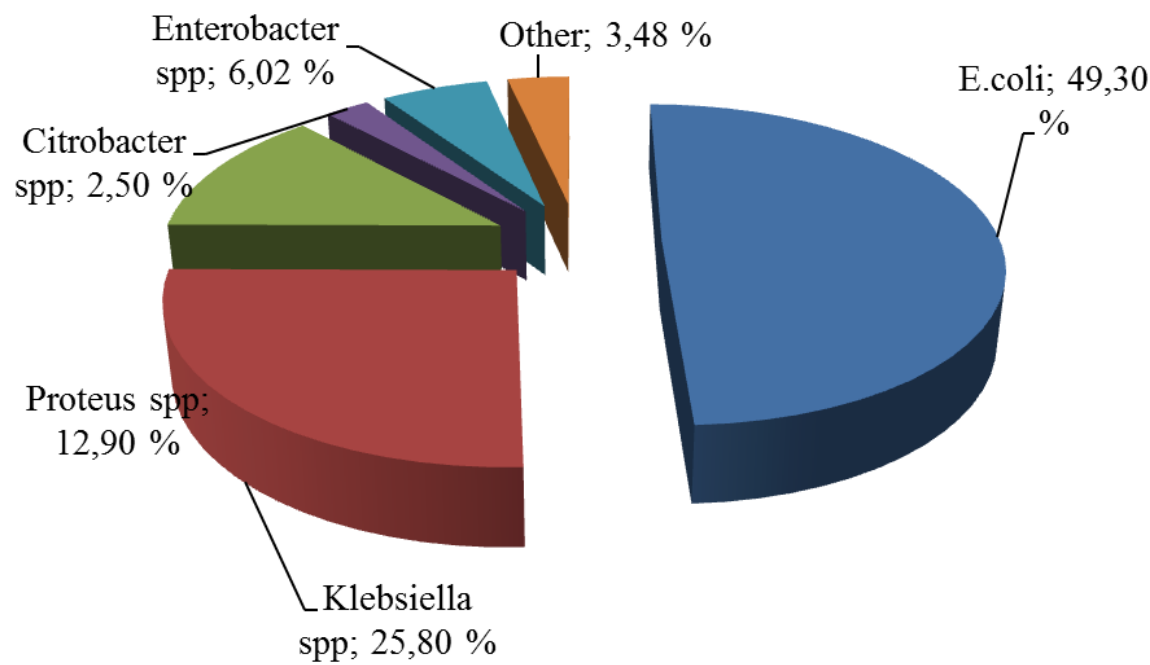

Fig. 3. Frequency of inoculation of Enterobacteriaceae microorganisms, separated in patients with genitourinary diseases 


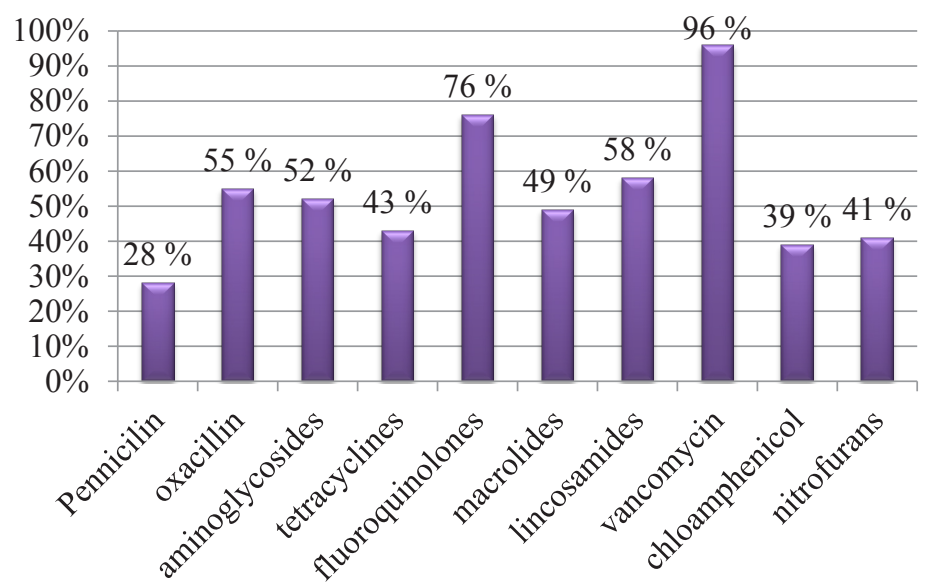

Fig. 4. Determination of sensitivity of staphylococci laboratory strains, separated in patients with inflammatory diseases of genitourinary tract, to antibiotics

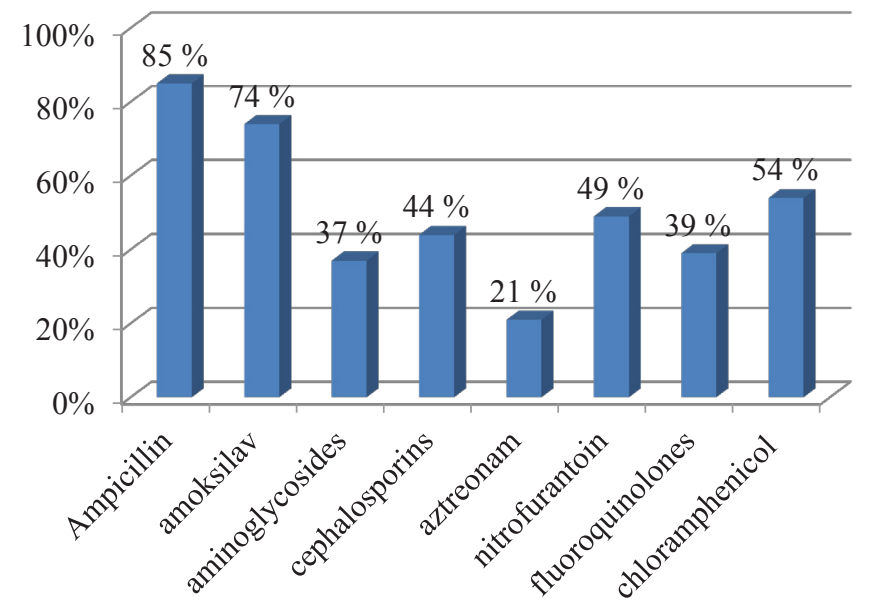

Fig. 5. Determination of resistance of laboratory strains of enterobacteria, separated in patients with genitourinary tract diseases to antibiotics

The retrospective analysis of MRSA, MR-CNS prevalence among separated staphylococci laboratory strains Fig. 6, 7) and $\beta(+)$ ESBL among isolated enterobacteria laboratory strains (Fig. 8) was also realized. Such attention to MRSA strains is conditioned by the fact that the essential share of diseases, caused by them, is connected with epidemic clones, able to intercontinental spread. MRSA lines, independently formed in different geographic regions, on different genetic bases are remarkable for increased virulence.

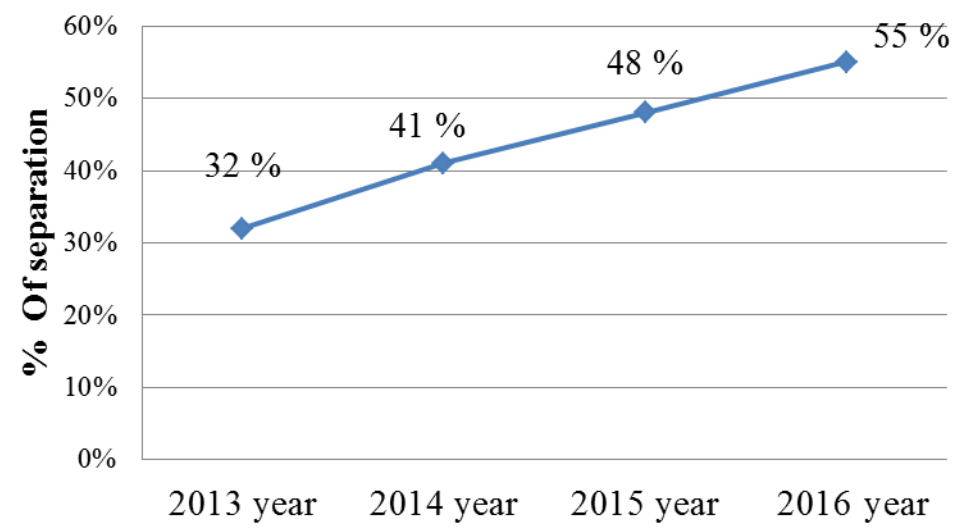

Fig. 6. Frequency of MRSA separation among isolated laboratory strains S.aureus 


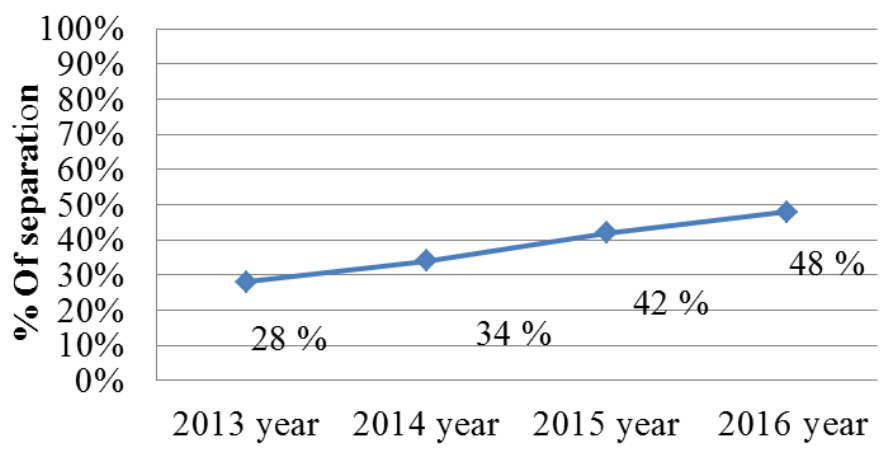

Fig. 7. Frequency of MR-CNS separation among isolated laboratory strains of coagulosonegative staphylococci

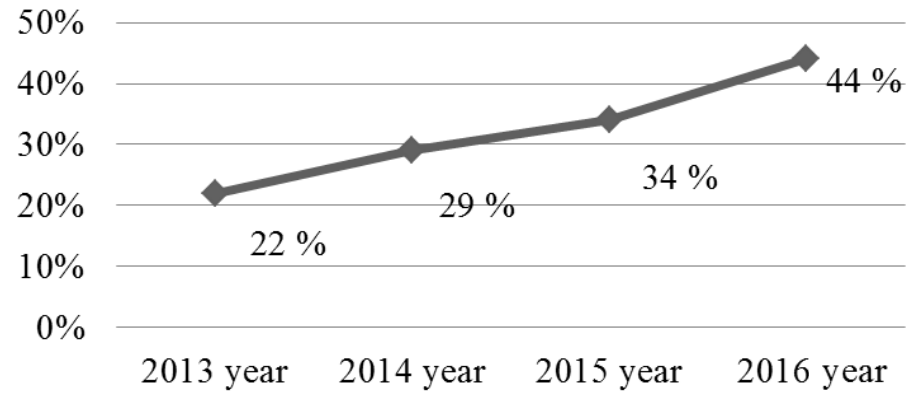

Fig. 8. Frequency of ESBL $(+)$ separation among isolated laboratory strains of enterobacteria

\section{Discussion of research results}

At realization of the bacteriological study, microorganisms, related to Staphylococcus genus and Enterobacteriaceae family were most often isolated in patients (31,3\% and 22,8 \% respectively) (Fig. 1). Representatives of other microorganisms' genera were separated in less percent of cases. These microorganisms were isolated both independently and in microbial associations. Associations were most often formed by staphylococci and enterobacteria both between each other and with representatives of streptococci, corynebacteria and micrococci genera. Among isolated staphylococci strains prevailed the ones with expressed pathogenic potential-S.haemolyticus and S. aureus (27,1\% and 13,9\% respectively) (Fig. 2). Among representatives of enterobacteria family the dominant positions were occupied by E.coli and Klebsiella spp (49,3\% and 25,8 \% respectively) (Fig. 3).

It is well-known that last 30 years the intensity of invention and elaboration of new antimicrobial drugs essentially decreased, in contrast to bacteria that continue to evolve and resist to elaborated antibiotics, increasing the number of practically untreated infections. At the same time the long antibiotic therapy, used for the treatment of infections, caused by obligate pathogens, results in selection of drug-resistant organisms and development of undesirable colonization or infection by multi-stable bacteria. During the study it was established, that separated staphylococci laboratory strains demonstrated the high sensitivity to fluoroquinolones, lincosamides $\quad(76,0 \%$ and $58,0 \%$ respectively), middle sensitivity to aminoglycosides, macrolides and tetracyclines $(52,0 \%, 49,0 \%$ and $43,0 \%$ respectively) (Fig. 4). Very low sensitivity to penicillin, chloramphenicol and drugs of nitrofuran series $(28,0 \%, 39,0 \%$ and $41,0 \%$ respectively). It may be connected with the fact that macrolides and tetracyclines are traditionally used for the treatment of infections, caused by obligate pathogens and in such a way favor the development of resistance in opportunistic pathogens. But the main factors of resistance development of opportunistic agents are the empirical inadequate antibiotic therapy and long-term use of antibiotics. At the assessment of sensitivity of separated staphylococci laboratory strains, polyresistant ones were revealed in $67,0 \%$ of cases, strains with extensive resistance in 7,0\% of cases, panresistant strains were not separated.

At the determination of sensitivity of enterobacteria laboratory strains to antibiotics, it was established, that isolated strains demonstrated the high resistance to both unprotected and protected penicillin (ampicillin - 85,0\%, amoksilav - 74,0 \%), middle resistance to cephalosporins and 
nitrofurans (44,0\% and 49,0\%), relatively high sensitivity to monobactames (aztreonam), aminoglycosides and fluoroquinolones (Fig. 5). Such little sensitivity to most $\beta$-lactame antibiotics is conditioned by the presence of lactamases of extended spectrum of effect in $\beta$-lactamase microorganisms $(\beta(+)$ ESBL). Polyresistant strains were isolated in 54,0 \% of cases, strains with extensive resistance $-5 \%$, panresistant strains were not separated.

At the retrospective analysis of MRSA, MR-CNS prevalence among separated staphylococci laboratory strains (Fig. 6, 7) and $\beta(+)$ ESBL among isolated enterobacteria laboratory strains (Fig. 8) it was established, that MRSA and MR-CNS strains growth in the studied period was $23,0 \%$ and $24,0 \%$, respectively. For $\beta(+)$ ESBL this index was $22,0 \%$ for the analyzed period.

The received data testify to the necessity of permanent microbiological monitoring of antibiotic resistance of microorganisms' laboratory strains to elaborate the rational treatment schemes and prevention of bacteria's resistant strains spread.

\section{Conclusions}

1. Antibacterial therapy must be started after receiving results of bacteriological study and determination of pathogens' sensitivity to antibiotics to maximally decrease the empirical therapy risks.

2. The determination of sensitivity of separated microorganisms to antibiotics must be realized taking into account their clinical and epidemiological importance and the assessment of sensitivity not to the concrete antibiotic (name) but to the group of antibacterial drugs.

3. The necessity of permanent microbiological monitoring with special attention to the "problem" agents: MRSA, MR-CNS and $\beta(+)$ ESBL is presented.

\section{References}

[1] Mavrov, G. I., Pinkovskaya, L. I., Orlova, K. S. (2014). Alternativniy podhod k etiotropnomu lecheniyu infektsionnyh vulvovaginitov i bakterialnogo vaginoza (obzor literatury i sobstvennye issledovaniya). Dermatologiya ta venerologiya, 4 (66), 21-34.

[2] Dzhoraeva, S. K., Goncharenko, V. V., Shcherbakova, Yu. V., Shchogoleva, O. V. (2016). Vyvchennya stany vaginalnoi microbioty pry vuvlovaginitah polimicrobnoi etiologii z vyznachennyam dominiuchih rivniv antybiotykochutlyvosti. Dermatologiya ta venerologiya, 2 (72), 25-33.

[3] Rakhmatulina, M. R. (2013). Sovremennye podhody k terapii vulvovaginitov, vyzvannyh uslovnopatogennymi mikroorganizmami, s uchetom antibakterialnoy rezistentnosti infektsionnyh agentov. Vestnik dermatologii i venerologii, 2, 44-52.

[4] Dzhoraeva, S. K., Goncharenko, V. V., Shchogoleva, O. V., Shcherbakova, Yu. V., Bezruchenko, A. A. (2015). Sklad ta funktsii mikrobiotsenoziv riznyh biotopiv makroorganizmu ta klinichna znachimist ih porushen. Dermatologiya ta venerologiya, 2 (68), 5-19.

[5] Glumchger, F. S., Dubov, S. O., Kuchin, Yu. L. (2014). Polirezistentnaya infekthiya: aktualnost, opredelenie, mehanizmy, naibolee rasprostranennye patogeny, lechenie, prophilaktika. Nauka i praktika. Mizhvidomchiy zhurnal, 1 (2), 129-149.

[6] Kulvagambetov, I. R., Tranozhnikova, L. P., Nurmanbetova, F. N., Sarsenbaeva, S. S. (2014). Mezhdunarodnye programmy profilaktiki i borby s antibiotikorezistentnostu. Izvestiya natsionalnoy Akademii nauk Respubliki Kazahstan. Seriya biologicheskaya i medichinskaya, 6, 65-72.

[7] Vozrastauschaya ugroza razvitiya antimikrobnoy rezistentnosti. Vozmozhnye mery (2013). Vsemirnaya organizaciya zdravoohraneniya, 130. Available at: http://apps.who.int/iris/bitstream/10665/ 44812/16/9789244503188_rus.pdf

[8] Ustoychivost $\mathrm{k}$ protivomicrobnym preparatam: globalnuy doklad po epidnadzoru (2014). Vsemirnaya organizaciya zdravoohraneniya, 257. Available at: http://www.who.int/drugresistance/documents/surveillancereport/en/

[9] Falagas, M. E., Karageorgopoulos, D. E. (2008). Pandrug Resistance (PDR), Extensive Drug Resistance (XDR), and Multidrug Resistance (MDR) among Gram-Negative Bacilli: Need for International Harmonization in Terminology. Clinical Infectious Diseases, 46 (7), 1121-1122. doi: 10.1086/528867

[10] Dzhoraeva, S. K., Goncharenko, V. V., Shchogoleva, O. V., Lyaschenko, O. A., Shcherbakova, Yu. V. (2015). Analiz dynamiky poshirennya metytsilinrezystentnyh shtamiv stafilokokiv u dermatovenerologichniy klinutsi. Dermatologiya ta venerologiya, 3 (69), 28-35. 
[11] Hoiby, N., Bjarnsholt, T., Givskov, M., Molin, S., Ciofu, O. (2010). Antibiotic resistance of bacterial biofilms. International Journal of Antimicrobial Agents, 35 (4), 322-332. doi: 10.1016/j.ijantimicag.2009.12.011

[12] Frakking, F. N. J., Rottier, W. C., Dorigo-Zetsma, J. W., van Hattem, J. M., van Hees, B. C., Kluytmans, J. A. J. W. et. al. (2013). Appropriateness of Empirical Treatment and Outcome in Bacteremia Caused by Extended-Spectrum-Lactamase-Producing Bacteria. Antimicrobial Agents and Chemotherapy, 57 (7), 3092-3099. doi: 10.1128/aac.01523-12

[13] Van Duin, D., Kaye, K. S., Neuner, E. A., Bonomo, R. A. (2013). Carbapenem-resistant Enterobacteriaceae: a review of treatment and outcomes. Diagnostic Microbiology and Infectious Disease, 75 (2), 115-120. doi: 10.1016/j.diagmicrobio.2012.11.009

[14] Johnson, L., Sabel, A., Burman, W. J., Everhart, R. M., Rome, M., MacKenzie, T. D. et. al. (2008). Emergence of Fluoroquinolone Resistance in Outpatient Urinary Escherichia coli Isolates. The American Journal of Medicine, 121 (10), 876-884. doi: 10.1016/j.amjmed.2008.04.039

[15] Kahlmeter, G. (2002). An international survey of the antimicrobial susceptibility of pathogens from uncomplicated urinary tract infections: the ECOmiddle dotSENS Project. Journal of Antimicrobial Chemotherapy, 51 (1), 69-76. doi: 10.1093/jac/dkg028

[16] Yurchishin, O. I., Kutsik, R. V. (2015). Synergizm protymikrobnoi dii spyrtovyh ekstractiv likarskyh roslyn z erytromitsinom vidnosno shkirnyh izolyativ Staphylococcus epidermidis z riznymy mekhanizmamy MLS-rezystentnosti. Actualni problemy borotby z infektsiynymy zahvoryuvannyamy. Kharkiv, 83.

[17] Pro zatverdzhennya metodychnyh vkazivok "Vyznachennya chutlyvosti mikroorganizmiv do antymikrobnyh preparative" (2007). MOZ Ukrainy, No. 167. Available at: http://ua-info.biz/legal/baselw/ ua-qmwjae/index.htm

[18] Ob unifikatsii mikrobiologicheskih (bakteriologicheskih) metodov issledovaniya, primenyaemih v kliniko-diagnosticheskih laboratoriyah lechebno-profilakticheskih uchrezhdeniy (1985). MZ SSSR, No. 535. Available at: http://www.alppp.ru/law/zdravoohranenie--fizicheskaja-kultura-i-sport--turizm/ zdravoohranenie/64/prikaz-minzdrava-sssr-ot-22-04-1985--535.html

[19] Baron, E. J., Miller, J. M., Weinstein, M. P., Richter, S. S., Gilligan, P. H., Thomson, R. B. et. al. (2013). A Guide to Utilization of the Microbiology Laboratory for Diagnosis of Infectious Diseases: 2013 Recommendations by the Infectious Diseases Society of America (IDSA) and the American Society for Microbiology (ASM)a. Clinical Infectious Diseases, 57 (4), e22-e121. doi: 10.1093/cid/cit278

[20] Critically Important Antimicrobials for Human Medicine. 4th Revision (2016). Vsemirnaya organizaciya zdravoohraneniya, 31. Available at: http://www.who.int/foodsafety/publications/antimicrobials-fourth/en/

[21] Magiorakos, A.-P., Srinivasan, A., Carey, R. B., Carmeli, Y., Falagas, M. E., Giske, C. G. et. al. (2012). Multidrug-resistant, extensively drug-resistant and pandrug-resistant bacteria: an international expert proposal for interim standard definitions for acquired resistance. Clinical Microbiology and Infection, 18 (3), 268-281. doi: 10.1111/j.1469-0691.2011.03570.x 